\begin{tabular}{|l|l|l||}
\hline \multicolumn{2}{|c|}{ PublisherInfo } \\
\hline \hline PublisherName & $:$ & BioMed Central \\
\hline \hline PublisherLocation & $:$ & London \\
\hline \hline PublisherImprintName & $:$ & BioMed Central \\
\hline \hline
\end{tabular}

\title{
Distinct Ras requirements
}

\begin{tabular}{|l|l|l||}
\hline \multicolumn{2}{|c|}{ ArticleInfo } \\
\hline \hline ArticleID & $:$ & 4558 \\
\hline \hline ArticleDOI & $:$ & $10.1186 /$ gb-spotlight-20020820-01 \\
\hline \hline ArticleCitationID & $:$ & spotlight-20020820-01 \\
\hline \hline ArticleSequenceNumber & $:$ & 224 \\
\hline \hline ArticleCategory & $:$ & Research news \\
\hline ArticleFirstPage & $:$ & 1 \\
\hline \hline ArticleLastPage & $:$ & 3 \\
\hline \hline & & RegistrationDate : 2002-8-20 \\
\hline ArticleHistory & $:$ & OnlineDate \\
\hline \hline ArticleCopyright & $:$ & BioMed Central Ltd2002-8-20 \\
\hline \hline ArticleGrants & $:$ & \\
\hline \hline ArticleContext & $:$ & 130593311 \\
\hline \hline
\end{tabular}




\section{Tudor P Toma}

Email: t.toma@ic.ac.uk

Tumors associated with oncogenic Ras in humans differ markedly from those in mice - which fail to form pancreatic, thyroid, or colon neoplasms - suggesting that the mechanism of Ras transformation may not be as universal as has been believed. In the August 15 issue of Genes \& Development, Nesrin Hamad and colleagues at Duke University Medical Center, Durham, North Carolina, US, confirm that the route to Ras oncogenesis varies between mammalian cells (Genes Dev 2002, 16:2045-2057).

Hamad et al. evaluated the role of specific effectors in mediating oncogenic Ras transformation in both human and murine cells. They observed that the signaling pathway activated by H-Ras $12 \mathrm{~V} 37 \mathrm{G}$ was sufficient for Ras-dependant transformation and necessary for tumor formation in human cells, and that RalGEFs were critical components of this process. They also noted that the two most critical effectors of Ras transformation of rodent fibroblasts were incapable, either alone, or in combination to cause transformation of the human cells.

"These observations highlight the value of dissecting the signaling pathways of oncoproteins in human cells and suggest that the effectors of H-Ras $12 \mathrm{~V} 37 \mathrm{G}$, such as RalGEF, could represent potential targets for the development of anti-Ras drugs for the treatment of human cancers," conclude the authors.

"The present study by Hamad et al. should cause appreciation of the fact that tumor biology in humans on the mechanistic level may not always be explicable by simple extrapolation from more tractable experimental systems like the mouse," comment Benjamin Boettner and Linda Van Aelst of Cold Spring Harbor Laboratory in an accompanying editorial.

\section{References}

1. Hamad NM, Elconin JH, Karnoub AE, Bai W, Rich JN, Abraham RT, Der CJ, Counter CM: Distinct requirements for Ras oncogenesis in human versus mouse cells.Genes Dev 2002, 16:2045-2057., [http://www.genesdev.org/cgi/content/abstract/16/16/2045]

2. Duke University Medical Center, [http://www.mc.duke.edu/index3.htm]

3. Cold Spring Harbor Laboratory, [http://www.cshl.org/]

4. Boettner B and Van Aelst L: The RASputin effect.Genes Dev 2002, 16:2033-2038., [http://www.genesdev.org/] 
